\title{
The market place in Korets town: from classicist creation to spatial dissolution
}

\author{
Petro Rychkov \\ Fuculty of Civil Engeneering and Architecture, Department of Conservation \\ of Built Heritage Lublin University of Technology \\ Wydziat Budownictwa i Architektury, Katedra Konserwacji Zabytków, Politechnika Lubelska
}

\begin{abstract}
The article is devoted to historical sources and spatial analysis of an original urban experiment in the first Polish Commonwealth. It was carried out in a small Korets town in Volhynia region during the last quarter of 18 th century. The proprietor of this old settlement prince Josef Clemens Czartoryski has initiated development and then practical realization of a new classicistic marketplace on the ground of the octahedral with eight radial streets. During the next two centuries, the characteristic pattern of this realization was gradually lost. However, due to cartographic sources, there is the opportunity to trace its spatial evolution and estimate their place in the history of town-planning art.
\end{abstract}

Kay words: Korets, classicism, urban structure, market place

\section{Introduction}

The reign of the last Polish king Stanisław August Poniatowski (1764-1795) was quite favourable for new architectural and urban planning initiatives. The king himself, who has got the unofficial title "king-architect"1, founded and introduced series of bold urban projects, encouraging at the same time to such activities the representatives of the magnate circles ${ }^{2}$. Not surprisingly, construction initiated by king often played the role of an effective pulse for such measurements in the aristocratic environment of the Polish Commonwealth ${ }^{3}$.

In general, the second half of the XVIII century was characterized in Poland by significant grows of interest to the implementation of new urban plans for the future development of cities ${ }^{4}$. Such innovations came organically into the public context of Enlightenment when the production and the needs of its architectural and spatial design become significant factors of new urban ideas. Such well-known example is the famous French town Chaux (Arc-et-Senans), designed in the concentric mode by French architect Claude-Nicolas Ledoux. Its construction began in 1775 and was completely subordinated to the functioning of the powerful saltworks. It is in this early industrial period when new types of urban buildings were elaborated, huge interest for spatial reform of settlements has awaked, the new urban concept of according to the principles of classicism has spread.

Classic new trends in Poland were also synchronized with the needs of the establishment in the cities of new opportunities for commodity production and to compete successfully in domestic and overseas markets. The most indicative in this sense is the activity of Lithuanian court Treasurer Antoni a noble Tyzenhaus (1733-1785), who founded a number of new cities during the 1760 's -1770 's $s^{5}$. Special scale differed the project of the new town Lososznia near Grodno. There should be a whole urban complex of industrial, administrative 
and residential units grouped around several round squares with radial streets ${ }^{6}$. Similar initiatives have spread across the Commonwealth. Even far from Warsaw, in Podolian town of Nemirov, Lieutenant-General of the Crown army Wincenty Potocki founded several guilds and created for the foreign masters new complex of residential buildings along the town main street ${ }^{7}$.

\section{New chances for Korets town}

The wave of classicistic urbanism couldn't affect other peripheral areas of the Polish Commonwealth, in particular, the Volhynian region. The interesting idea of creating a new market square on the expressive classic principles had been implemented in small Korets ${ }^{8}$ town by its owner Prince Clemens Józef Czartoryski (1740-1810). He was a Knight of the Order of the White Eagle, awarded to him in 1767. He owned the old Korets castle and has rebuilt it in the late baroque stile in the 1780s (now ruined). For several years he studied in Germany, visited other European capitals. After returning home he tried to introduce the German experience of production managing and even dressed as a German man $^{9}$.

A sufficiently long period of his life, from 1765 to 1788, was associated almost continuously with the stay in his ancestral town of Korets in Volhynia. As a prudent owner and ambitious entrepreneur, he founded, even their own "Economic school". He was a Knight of the Order of the White Eagle, awarded to him in 1767. Some authors relate to the merits of this Prince the first attempts of modern industrial foundations in Volhynia. Even his leadership among other Polish entrepreneurs of those years, such as Prot Potocki, Michael Lubomirski, Tadeusz Czacki and others, was recognized ${ }^{10}$. Already in 1778 Józef Czartoryski was able to procure for his town two-week fair which was, obviously, a logical consequence of the successful functioning of his craft guilds. And when the majority of Polish business enthusiasts after the last division of Polish Commonwealth (1795) suffered a financial collapse, the Czartoryski's economy continued to flourish in the first decade of the 19th century.

So, Korets became the main center of business plans initiated by its owner. This was at that time a small settlement in central Volhynia, previously possessed by the old princely ruthenian dynasties of Zaslvski, Ostrogski, Sangushko, Koretski. In 1788 the population of the small town consisted of up to 2 thousand ${ }^{11}$, it was a significant indicator at that time. Among the operated businesses there were tannery, brewery and "mead brewery", mills, a large tobacco warehouse, factories of iron, belts, furniture, hats, clothes, linen, and so on. But the greatest publicity in Poland and even abroad obtained the famous manufactory of pottery and porcelain. For its establishment on 17 September 1783, the Prince signed a special contract with the well-known German master Franz Moser ${ }^{12}$.

Image of Korets as a local handicraft and trade center remained in the second half of the 19th century, although the production of the famous Korets ceramics ceased in $1832^{13}$. It was noted in memoirs that this town is a home for the wealthy grain and forest merchants, which compete with each other in trade and bombast. Meantime the economic rise of the City certainly contributed to the architectural development of the Town. There were many stately homes, and the family manor of local merchant Gorenstein consisted of several small palaces and was similar to a magnificent aristocratic residence ${ }^{14}$. Obviously, to the landscaping of the central town part had German specialists, many of which arrived at Korets on the invitation of the Prince Czartoryski. The successful development of local production and trade, of course, stimulated new urban ideas too.

7 Rychkov P. Niemirów na Podolu - zapomniany eksperyment urbanistyczny doby stanisławowskiej // KAiU, t.LX, zeszyt 2/2015, p. 6-7.

8 Ukrainian: Корець, Russian: Корец, Polish: Korzec, Yiddish:

9 Niec J. Czartoryski Józef Klemens (1740-1810) // Polski Słownik Biograficzny. - Kraków, 1937. - t. IV/1, zeszyt 16, s. 279.

10 Nieć J. Twórca przemysłu wolyńskiego // Ziemia Wołyńska. - 1938, N 6. - S. 94.

11 Nieć J. Twórca przemysłu... s. 95.

12 Ibidem.

3 Encyklopedia kresów. Kraków, 2005, s. 205.

14 Słownik Geograficzny Królestwa Polskiego i Innych Krajów Słowiańskich. T. IV. - Warszawa, 1883, s. 432. 


\section{Creation of regular marketplace}

The historic core of the old Korets was formed yet in old times on the right cape bank of the Korchyk river and the settlement was firstly mentioned in chronicles at 1150 . On this high place a defensive castle was installed, from its Northern side, the old town was gradually formed. Even then, not far from the castle, the spatial town core was formed as the future marketplace, on the spatial parameters of which there is no detailed information. And when in the last two decades of the 18th century, the city has made significant progress in economic development, it was decided to fix these positive changes in a new urban form. Finally, in the middle of the town, the new market square was created in accordance with the popular classicistic principles. Thus, the city has got here an interesting example of the coherent spatial realization of the urban experiment in the form of a centric marketplace.

Obviously, the architectural creation of this place in Korets was a logical result of the economic prosperity of this town. We can also assume that the immediate impetus for the emergence of such new areas in the existing urban structure resulted, on the one hand, from the representative intentions of local German community, and, on the other, from the practical necessity of spatial permanent site for trade, both for daily retail and occasional fairs.

The initial draft plan for the new market square in Korets is unknown. It is also unknown the exact time of its creation and execution. However, until our time has come to a very interesting copy of an old drawing, which dates from 1809, i.e. it was created already during the Russian administration ${ }^{15}$ (Fig.1).

The author of the picture carefully reproduces not only the buildings directly surrounding a new marketplace, but also an essential part of the entourage. The figure also contains the corresponding names of adjacent streets and some objects (the earth wall, city gate, bridge, Jewish schools, parish Church). The surrounding buildings were shown only fragmentarily in two South-Eastern sectors ${ }^{16}$. These sectors are limited from the East with a clear boundary in the form of earthworks (hitherto not preserved). Location plan of these two sectors is mostly linear, without the explicit order. Hence, there are grounds for the assumption that new market square creation affected only the Central part of the old town.

The formal composition of the market square was formed in the shape of a regular octahedron, i. e. it clearly symbolizes classic perfection. Simultaneously, it was introduced centric planning scheme with eight radial streets (otherwise with four diameters). One of the diameters fit into the city's main street. In the middle of each eight place sides, between the market houses were arranged passages, which have continued in the form of a centrifugal radial streets. The main direction was "East-West" (it is Franciscan-St on the figure), which also actually provides transit traffic through the town. Other radial streets had local significance and were going to the castle, estate, farms, monastery, new town, Jewish quarters.

Buildings around the market square were obviously characterized by similar shapes and were apparently used for commercial purposes. According to the plan, all 24 buildings around the marketplace are similar in size too, which may reflect also uniformity of their architectural images. Four major entrances to the place area ("East-West" and "North-South") were flanked with two pairs of symmetrical buildings. The other four entrances in the diagonal directions had on both sides only one building. This feature in the localization of the buildings was probably non-accidental. She contributed to a certain compositional enrichment of the internal space of the square, emphasizing its role as functional and spatial dominant in the old town historic area (Fig. 2).

\section{Spatial decomposition of the marketplace}

"Survival" in the live urban space of such holistic urban object as the marketplace in Korets depended on many circumstances. Overall, there were many destructive factors, associated primarily with the new political, social, economic and even demographic circumstances. Therefore, this decomposition process stretches back in time during the $19^{\text {th }}$ and $20^{\text {th }}$ centuries.

15 Politechnika Warszawska, Zakład Architektury Polskiej. Zbiór pomiarów (PW ZAP), inw. N: U-1-2. Plan miasta Korca. Rys. G. Denderowicz (kopia).

16 Note: on this map the North direction is facing down. 
So, on the later plan of the city, prepared by Russian administration in 1822 , the marketplace is still reasonably articulated and has only a small spatial deformation ${ }^{17}$ (Fig. 3). However, these can be attributed to purely drafting defects. There is clearly shown that the area planned for spatial center of historic part of the town still exists in the form of a regular octagon, although other important sites (old castle, Orthodox church, Franciscan monastery) are shown very simplistic. As before, the buildings around the square were divided into eight identical parts. The street network of the town is reflected in a very conditional mode and is not harmonized with the shape of marketplace. Only the main transitive street in direction "East-West" is reflected in the picture. At the time of making this plan, any other signs of urban regularity are not noticeable. Also, the external defense rampart in the form of the earthworks was fixed from the East side, near the Franciscan monastery.

The next archival map of the town is a document dating back to $1860^{18}$ [16] (Fig. 4). In general, it confirms the classicist layout of the market square and its initial geometry in the internal front of still existing market buildings. However, at the same time, he demonstrates the frequent and rather chaotic changes of the surroundings in terms of their sizes and geometric configurations. Some fragments of the radial centrifugal streets are here still visible. However, the surroundings are already formed on the basis of orthogonality and are not coherent with the initial urban plan. Interesting detail: areas of the main strip and the new telegraph line are specifically shown on this plan.

Further transformations of the buildings around the marketplace are well marked on the later plan from $1886^{19}$ (Fig. 5, 6). There were several reasons for changes. One of them was connected with the great fire in the town on June 29, 1881. Several hundred homes were destroyed, among them were also some houses and shops on the marketplace.

In the 1930-s, when Korets belonged to the second Polish Commonwealth, it was compiled another cartographic document (in very sketchy manner). There were shown only two local fragments of old diagonal streets by the north side of the main road $^{20}$ (Fig.7).

Over the next half a century the destruction both of the spatial structure of the marketplace and surrounding buildings continued at the beginning of 1920 -is, their destruction became even more expressive ${ }^{21}$ (Fig. 8a).

Finally, the process of spatial "dissolution" of the place area came to the end in Soviet Union times. In the second half of the 20th century along the South side of the main street, several new public objects were alternately built, creating thus a solid front of buildings on this side of the street. But the North side of this street has partly preserved open space on the former site of the old marketplace. However, its spatial boundaries from the North were formed by the four modern public buildings. Because these new buildings the open space received a rectangular shape, which finally eliminated the "genius loci" of the urban past. These changes are clearly illustrated by the latest satellite image of 2011 (Fig. 8 b).

\section{Conclusion}

The example of marketplace creation in Korets confirms the constructive role of influential and wonderfully rich magnates in the Volhynian soil. The local experiment in the spirit of classicism, conceived and embodied in this small town in 1780-is, is the real positive proof of the constructiveness of this role. This action of Prince Józef Czartoryski became a self-sufficient incarnation of a new urban philosophy in a peripheral historical context. In its creative basis were laid popular classic ideas, widely spread in the urban practice of the first Polish

17 Российский государственный военно-исторический архив (РГВИА). Фонд ВУА, д. 19553. «План окрестности м. Корца, снятый в 1822 году»..

18 Российский государственный исторический архив (РГИА). Ф.1289, о.15, д.59, л.1. «План местечка Корца с показанием направления телеграфной линии. Составлял подполковник Маслаковец».

19 Державний архів Рівненської області (ДАРО). «План Волынской губернии, Новоградволынского уезда, местечка Старого Корца имение князя Артура Яблоновского. Составлен в 1886 году». The document is not taken into archival register. The author expresses his gratitude to the historian Victor Luts for providing a copy of this map.

20 ДАРО, «Plan miasta i przedmieści Korca». Fragment.

21 Archiwum Akt Nowych (AAN) w Warszawie, MSW 298. «Plan miasta i przedmieści Korca w powiecie Rówieńskim. Odrys sporządził 12. III. $1930 \mathrm{r}$. Techik mechanik (podpis nieczytelny)». The author is grateful to O. Mykhailyshyn for providing a copy of this document. 
Commonwealth ${ }^{22}$. The possibility to execute in their possession relevant urban ideas were considered by the owner in several aspects: as a demonstration of his high social status, as a confirmation of his own economic potential, as the introduction of new progressive forms of management and, at the end, as a demonstrative care of the urban aesthetics. That is why in the architectural historiography it was noted that this local phenomenon looks as quite specific, revealing, and so, no doubt, it deserves special attention ${ }^{23}$.

In general, this implementation has convincingly demonstrated the knowledge of the city owner Prince Józef Czartoryski, concerning the classic trends in Western Europe. It certainly can be considered as an original and unique reflection of urban sentiments in that historical époque. At the same time, knowledge of this local peculiarities both about their creation and then gradual "disappearance", allows us much better to see in the contemporary spatial structure of the Korets town erased traces of searching for urban perfections, to assess the past achievements, and on this basis to predict future prospects.

Streszczenie: Artykuł jest poświęcony źródłom historycznym, analizie morfologicznej oraz następnemu zaniku dawnego już nie istniejącego placu rynkowego w miasteczku Korzec na Wołyniu. Ten eksperyment urbanistyczny na południowo-wschodnich kresach pierwszej Rzeczypospolitej został dokonany w ostatniej ćwierci XVIII wieku pod patronatem właściciela tej osady książę Józefa Klemensa Czartoryskiego, który zainicjował w historycznej dzielnicy tego miasta założenie klasycystycznego placu rynkowego z ośmiu promieniowymi ulicami. Stopniowo w ciągu kolejnych dwóch wieków szczególne cechy tej realizacji zostały prawie całkowicie zatarte. Jednak dzięki źródłom kartograficznym istnieje możliwość prześledzić ewolucję historyczną tego zjawiska i ocenić jego miejsce w historii nowoczesnej urbanistyce.

Słowa kluczowe: Korzec, klasycyzm, układ urbanistyczny, plac rynkowy

\section{Illustrations}

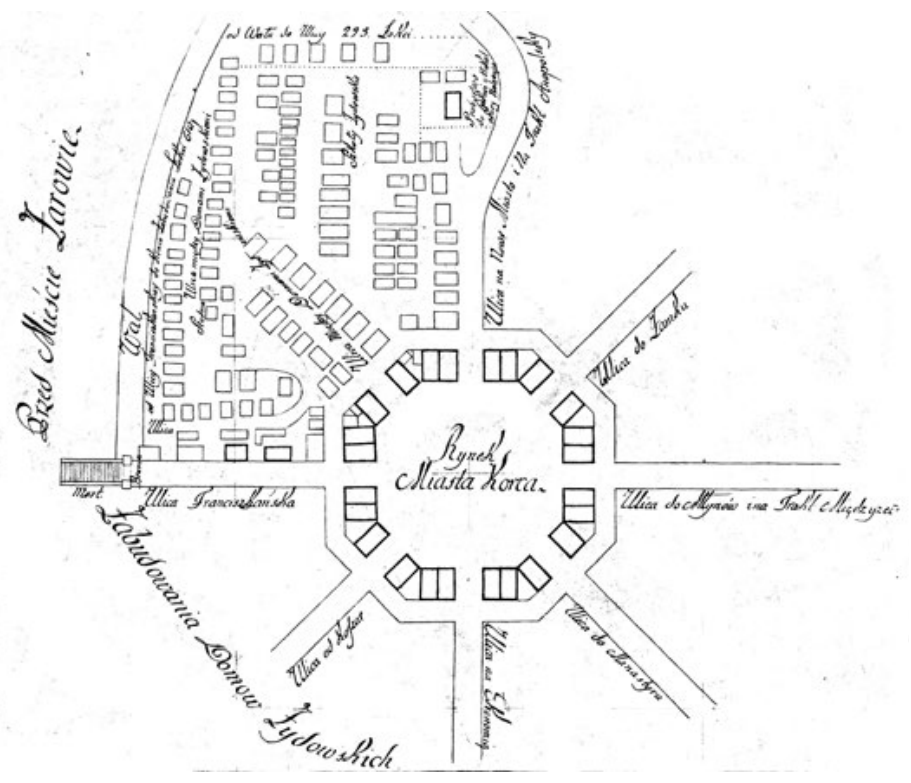

Fig. 1. Korets. Measuring picture of the marketplace. Author: R. Denderowicz. 1809. At: PW ZAP.

Korzec. Rysunek pomiarowy płacu rynkowego. Author: R. Denderowicz. 1809 r. Wg: PW ZAP.

22 Wyrobisz A. Miasta prywatne w Polsce XVI - XVIII w. jako inwestycje kulturalne // Kwartalnik Historii Kultury Materialnej. - R.XXVI, 1978. N1, s. 48 .

23 Trzebiński W. Działalność urbanistyczna magnatów i szlachty w Polsce XVIII wieku. - Warszawa, 1962, s. $133-134$. 

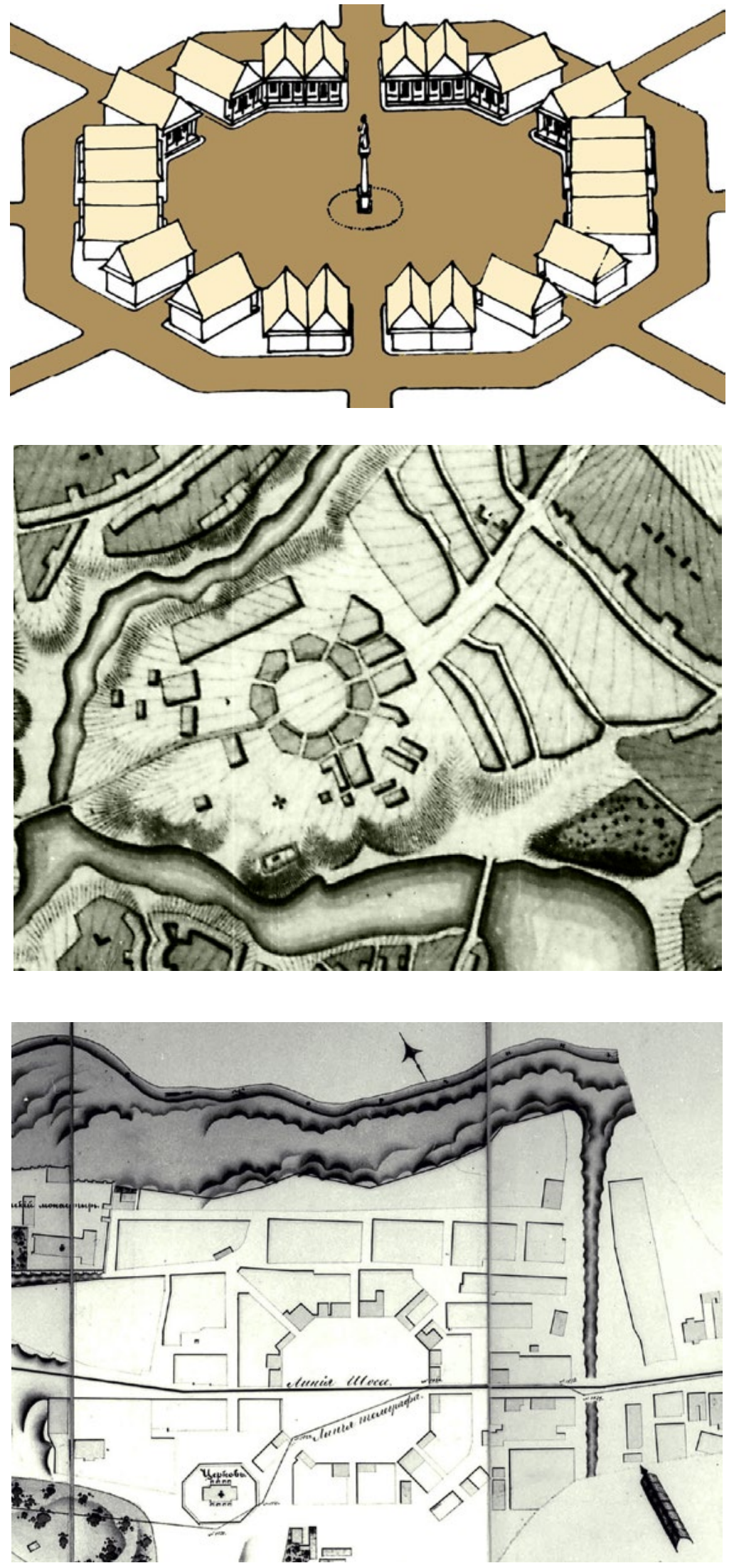

Fig. 2. Korets. General view of the marketplace. Graphic reconstruction by P. Rychkov.

Korzec. Widok ogólny placu rynkowego. Reconstrukcja graficzna R. Rychkov.
Fig. 3. Korets. The market square in the structure of the old town. 1822. Fragment. At: РГВИА

Korzec. Plac rynkowy w strukturze starego miasta. 1822. Fragment. Wg: РГВИА.

Fig. 4. Korets. Market area as it was 1860. Fragment. At: РДИА.

Korzec. Plac rynkowy według stanu na 1860 r. Fragment. Wg: РДИА. 

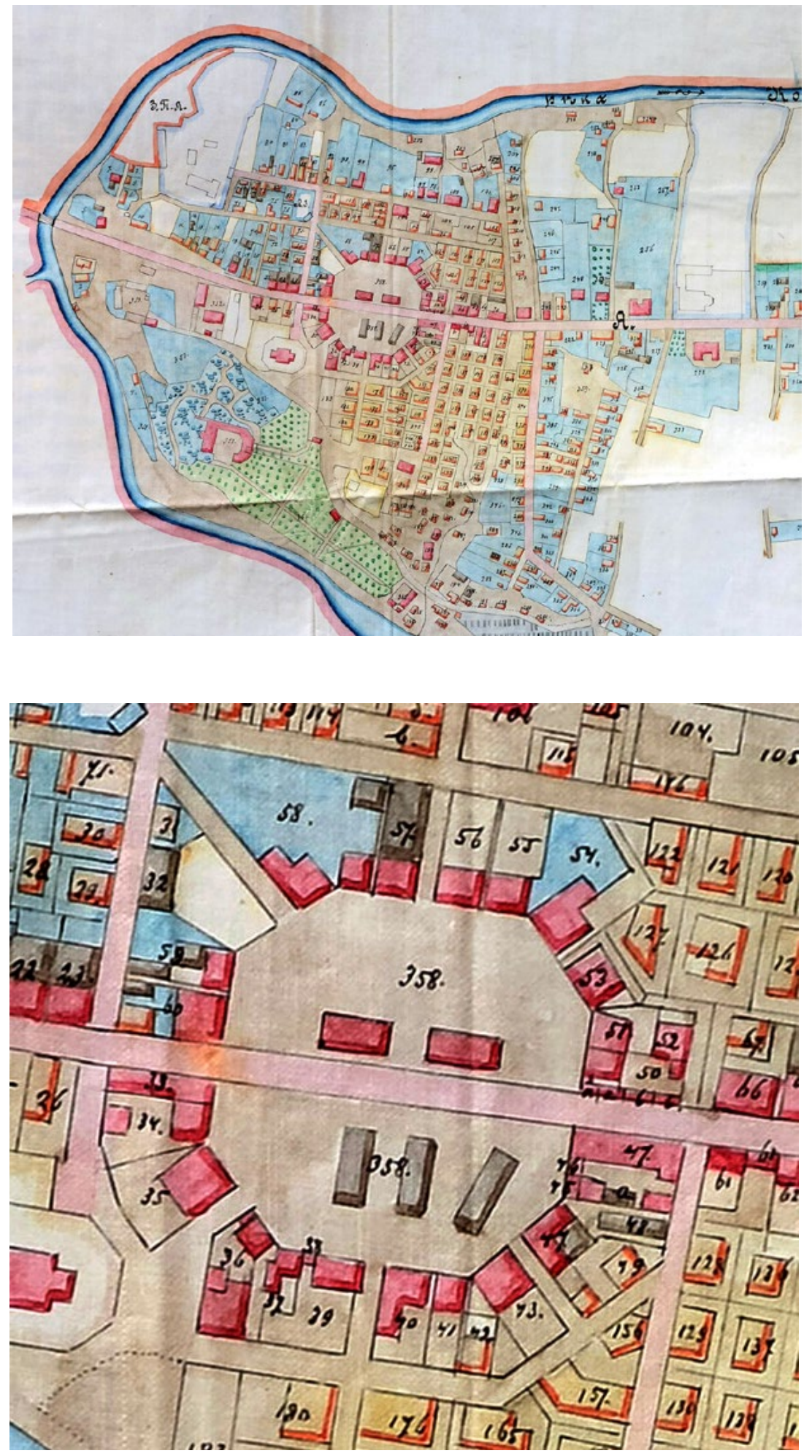

Fig. 5. Korets. The marketplace in the zone of the old town. 1886. At: ДАРО.

Korzec. Plac rynkowy w strukturze strefy starego miasta. 1886 r. Wg: ДАРО.
Fig. 6. Korets. The area of the marketplace. 1886. Fragment. At: ДАРО.

Korzec. Przestrzeń placu rynkowego. 1886 r. Fragment. Wg: ДАРО. 


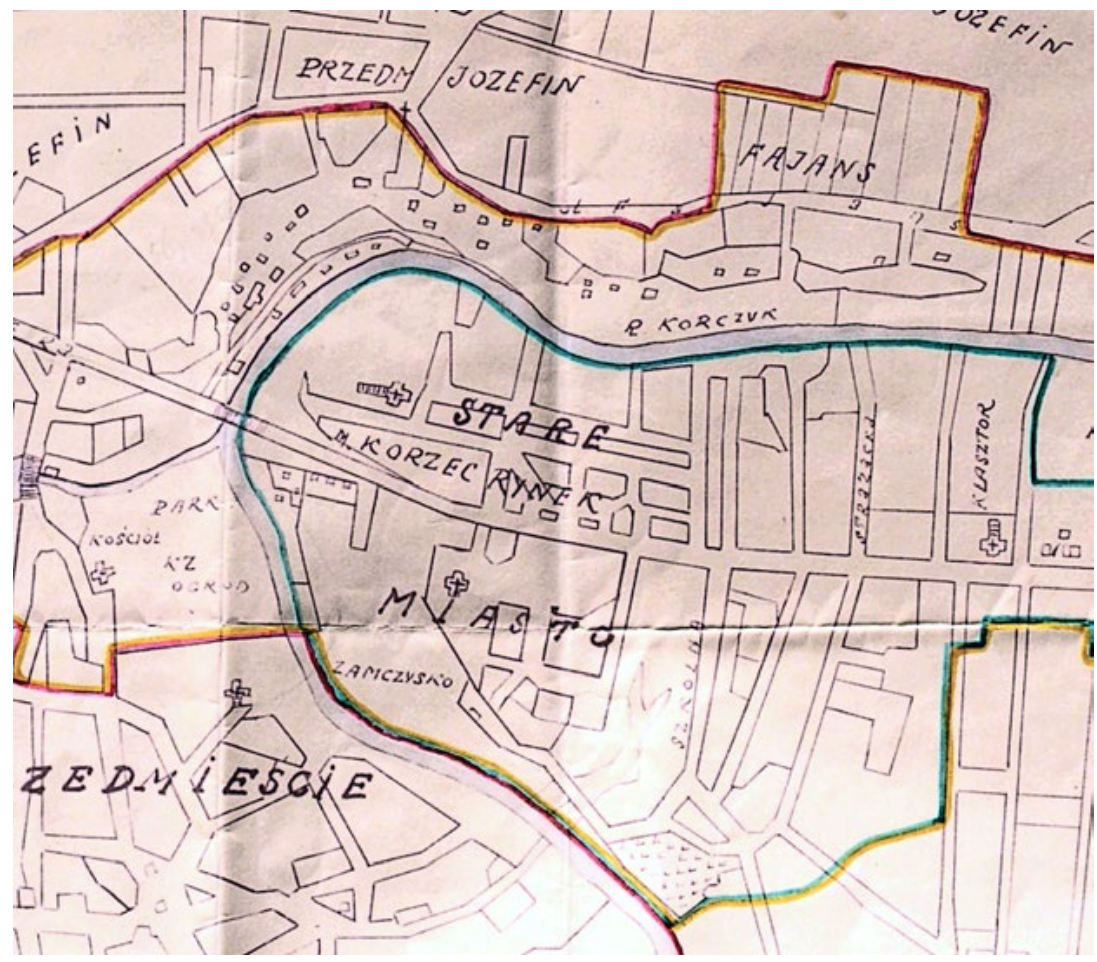

Fig. 7. Korets. The marketplace in the urban structure. 1930s. Fragment. At: ДAPO.

Korzec. Plac rynkowy w strukturze miasta. Lata 1930-e. Fragment. Wg: ДАРО

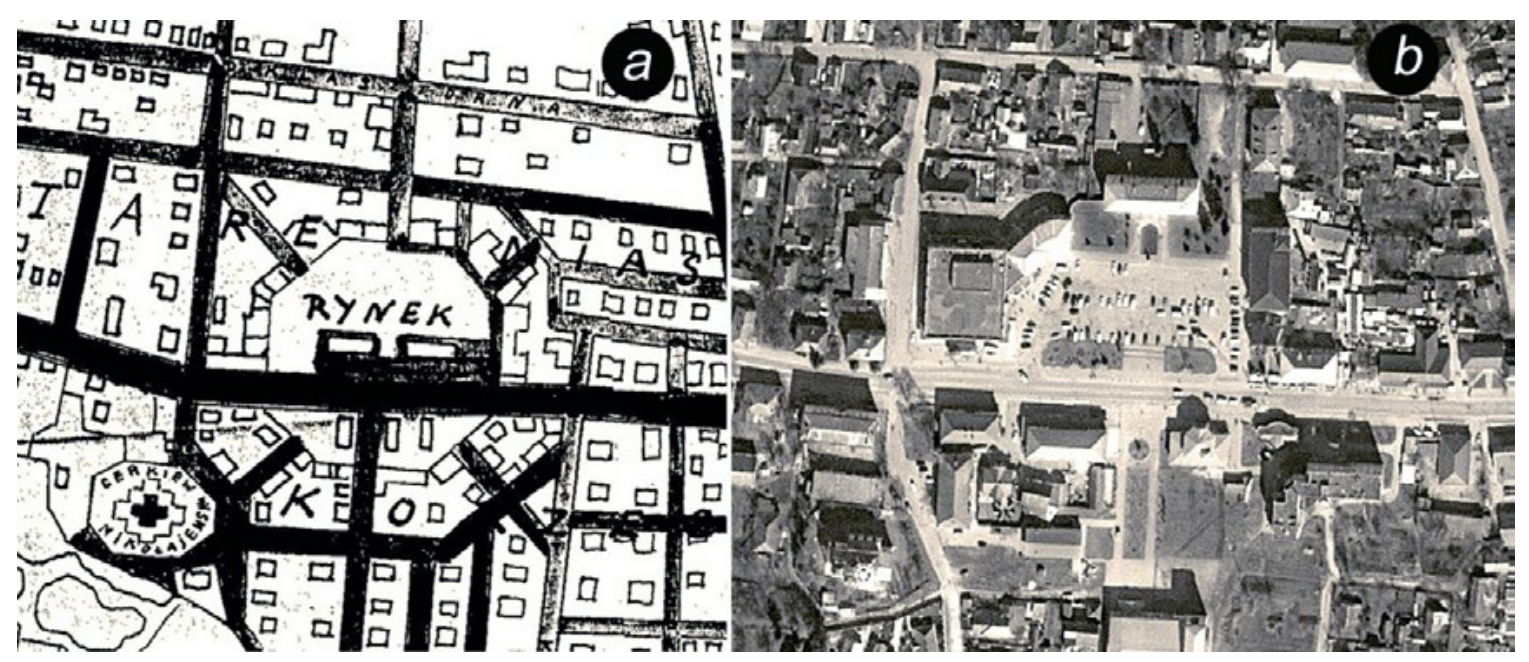

Fig. 8. The marketplace: $a$ - area of the marketplace in the 1920s. Fragment. At: AAN; b - contemporary buildings on the territory of former marketplace. At: GoogleEarth (2011 r.).

Korzec. Plac rynkowy: a - zabudowanie rynku stanem na lata 1920-te. Fragment. Wg.: AAN; b - współczesne budowle na miejscu dawnego placu rynkowego. Wg: GoogleEarth (2011 r.). 